\title{
Effect of Stocking Density and Supplemental \\ Ascorbic Acid on Growth, Organ Weight, \\ Mixed Function Oxidase in Hepatic \\ Microsomes, Lipid Metabolism and \\ Plasma Corticosterone in Male \\ Broiler Chicks
}

\author{
Kazuaki TaKahashi, Hitoshi Nishimura, \\ Yukio AkiBA and Masaaki Horiguchi \\ Department of Animal Science, Faculty of Agriculture, \\ Tohoku University, Aoba-ku, Sendai-shi 981
}

(Received January 14, 1991)

\begin{abstract}
The experiment was conducted with male broiler chicks to determine if stocking density and/or dietary ascorbic acid (AA) affect growth, organ weight, lipid metabolism, mixed function oxidase (MFO) in hepatic microsomes and plasma corticosterone concentration. Chicks ( 7 days of age) were housed in cages at 217,325 and $625 \mathrm{~cm}^{2}$ per chick. The chicks in each stocking density were given a diet supplemented with or without $0.2 \%$ AA for 14 days. The stocking density and/or supplemented AA did not affect body weight gain and feed efficiency for 14 days. Body weight gain, however, tended to decrease with the increased stocking density in chicks fed the diet without AA. The thymus weight was significantly decreased by the density of $217 \mathrm{~cm}^{2} /$ chick regardless of being supplemented with AA. The plasma cholesterol and lipid concentrations decreased with the increased stocking density and the supplemented AA, but the carcass fat content did not differ between treatments. The supplemental AA significantly decreased plasma corticosterone concentration. The components of MFO, cytochrome b5 and NADH-cytochrome b 5 reductase, decreased with the increase in stocking density. The supplemental AA increased the contents of cytochromes $\mathrm{P}-450$ and $\mathrm{b} 5$, but decreased the activity of NADPH-cytochrome $c$ reductase. The plasma corticosterone concentration correlated negatively with the content of cytochrome b 5 and the activity of NADH-cytochrome b 5 reductase per $100 \mathrm{~g}$ of body weight. These results show that stocking density and/or AA administration altered lipid metabolism, the components of the hepatic microsomal MFO and the plasma corticosterone concentration under the condition that they did not infuence growth and feed utilization. The supplemental AA is a modifier of MFO even in chicks kept under nutritionally proper conditions. In addition, the effect of ascorbic acid on lipid metabolism and the plasma corticosterone appeared to be associated with the changes in the some components of the MFO.
\end{abstract}

Anim. Sci. Technol. (Jpn.) $62(9): 829-838,1991$

Key words : stocking density, ascorbic acid, lipid metabolism, mixed function oxidase, broiler 
Animals reared in stressful conditions resulted in the reduction of growth, feed utilization, and immunoresponse ${ }^{25}$. Stocking density is a stressor and affects growth, reproductivity and plasma corticosterone concentration in hens ${ }^{11}$ ' and broilers ${ }^{32}$. Plasma corticosterone concentration is a candidate physiological indicator of animals subjected to stressor (s) ${ }^{15,17,24)}$. Administration of glucocorticoids to chicks increased body fat deposition and decreased body protein retention ${ }^{4,5)}$, and immunity ${ }^{16,19,30}$, Moreover, Aкiва et al. ${ }^{2 \prime}$ showed a significant positive correlation between plasma corticosterone concentration and abdominal fat weight in chicks kept in a proper nutritional and environmental condition.

Hepatic microsomal mixed function oxidase (MFO) is responsible for metabolizing steroids in chicks as well as mammals ${ }^{41}$. TAKAHASHI and JENSEN ${ }^{42}$ postulated that the MFO in hepatic microsomes was possibly activated by ascorbic acid (AA). Furthermore, Pardue and THAXTON ${ }^{30}$ noted that supplemental AA ameliorated the immunosuppression associated with exogenous cortisol. Supplemental AA also improved heat resistance and mortality associated with elevated environmental temperature ${ }^{30,31)}$ and increased egg production and the hatching of fertile eggs in broiler breeders $^{33}$. Thus, AA would be an anti-stress nutrient though it is not an essential nutrient in chicks kept in proper nutritional and environmental conditions. It, therefore, appears that improvement in growth, nutrient utilization, and immunoresponse by supplemental AA in chicks subjected to stressful conditions could be, in part, associated with an activation of the MFO in hepatic microsomes. This experiment was undertaken to determine if the administration of AA and stocking density would affect growth, lipid metabolism, activity of MFO, plasma corticosterone and immunocompetent organs in chicks.

\section{Materials and Methods}

Male broiler chicks (7 days of age) were housed in wire floor cages and given a 24 hour photoperiod. The chicks were allotted randomly to twelve pens of 2 each, and six pens of 4 or 6 each to achieve stocking density of 650,325 , $217 \mathrm{~cm}^{2}$ per chick. Half of the pens in each stocking density were provided a basal diet (Table 1). The remainder were fed a diet containing $0.2 \% \mathrm{AA}$. Feed and water were given ad libitum. At 21 days of age, the chicks and remaining feed were weighed. Six chicks from each stocking density were randomly selected and placed in a box and taken to an adjoining place where blood was taken from a heart. The chicks were bled for less than $3 \mathrm{~min}$ and plasma was separated by the centrifuge at $1,500 \times \mathrm{g}$ for $15 \mathrm{~min}$ and stored until analysis. After bleeding, the chicks were killed and organ weight was determined. Carcasses and plasma were kept at $-20^{\circ} \mathrm{C}$. For determination of mixed function oxidase in hepatic microsomes, half of the liver were placed in $0.1 \mathrm{M}$ Tris $-\mathrm{HCl}$ buffer ( $\mathrm{pH} 7.40)$ at $0^{\circ} \mathrm{C}$ and replaced in ice-cold $0.25 \mathrm{M}$ sucrose in the buffer, minced and soaked over $10 \mathrm{~min}$. The liver was homogenized in the

\section{Table 1. Composition of basal diet}

\begin{tabular}{lr}
\hline \hline \multicolumn{1}{c}{ Ingredients } \\
\hline \\
Corn & $(\%)$ \\
Soyben meal & 58.86 \\
Soy protein & 30.00 \\
Soyben oil & 3.00 \\
Calcium phosphate, Dibasic & 4.00 \\
Calcium carbonate & 1.72 \\
Sodium chrolide & 1.26 \\
PL-Methionine & 0.32 \\
Vitamin mixture ${ }^{1)}$ & 0.25 \\
Mineral mixture & 0.40 \\
\hline Calculated analysis & 0.42 \\
Metabolizable energy (kcal/kg) & 3150 \\
Crude protein (\%) & 21.5 \\
\hline 1) See AkiBa and Marsumoto (1978)
\end{tabular}


buffer with Ultradispaser (Yamato Co. Ltd., Japan) for 15 seconds at $0^{\circ} \mathrm{C}$ and then centrifuged at $10,000 \times \mathrm{g}$ for $10 \mathrm{~min}$ twice. To the supernatant we added calcium chloride (final concentration, $8 \mathrm{mM}$ ) stirred it for 10 $\min$ at $4^{\circ} \mathrm{C}$, and spun it at $20,000 \times \mathrm{g}$ for $40 \mathrm{~min}$ at $4^{\circ} \mathrm{C}$. The pellet was resuspended in the buffer with $0.15 \% \mathrm{KCl}(\mathrm{pH} \mathrm{7.4)}$ and spun again under the same conditions. The microsomal pellets were suspended in $20 \%$ glycerol in $0.1 \mathrm{M}$ Tris- $\mathrm{HCl}$ buffer and used for assay within 3 days. Cytochromes $\mathrm{P}-450$ and b5 were measured by the method of OMURA and SATO ${ }^{291}$. $\mathrm{NADPH}$-cytochrome $\mathrm{c}$ and NADH-cytochrome b 5 reductases were measured by the methods of PHILLIPS and LANDON ${ }^{35}$, and TAKESUE and OMURA $^{44}$, respectively. Plasma cholesterol and lipids were determined by the methods of ZURKOWSKI $^{47}$ and BRAGDON ${ }^{8)}$, respectively. Plasma corticosterone was extracted by the method of ScoTT and Dixon ${ }^{37)}$ and determined using a reverse phase high performance liquid chromatography ${ }^{14)}$. Carcasses were grounded by a meat chopper and a portion of the grounded carcasses were extracted by the method of Folch et $a l^{13}{ }^{13}$ and then weighed. Data were analyzed by the $2 \times 3$ factorial model with interaction using the General Linoar Models Procedure of Statistical Analysis system ${ }^{39}$.

\section{Results}

Table 2 shows the effect of supplemental AA and/or stocking density on body weight gain, feed efficiency, and weights of the liver, spleen, bursa Fabricius and thymus per unit of $100 \mathrm{~g}$ body weight in chicks. Body weight gain and feed efficiency did not significantly differ between treatments. The higher stocking density, however, resulted in a tendency toward increasing body weight gain in chicks fed the basal diet. The supplemental AA did not affect body weight gain. The higher stocking density reduced relative liver weight regardless of supplement with AA. The weights of the

Table 2. Effect of supplemental ascorbic acid (AA) and/or stocking density on weight of liver, spleen, bursa Fabricus and thymus per $100 \mathrm{~g}$ body weight in chicks

\begin{tabular}{|c|c|c|c|c|c|c|}
\hline $\begin{array}{l}\text { AA ( } \%) \\
\left.\text { Density ( } \mathrm{cm}^{2} / \text { chicks }\right)\end{array}$ & 625 & $\frac{0}{325}$ & 217 & 625 & $\frac{0.2}{325}$ & 217 \\
\hline Body weight gain ( $\mathrm{g} / 14$ & s) $487 \pm 16$ & $493 \pm 19$ & $529 \pm 3$ & $501 \pm 27$ & $496 \pm 8$ & $501 \pm 18$ \\
\hline Feed efficiency & $0.64 \pm 0.03$ & $0.67 \pm 0.04$ & $0.62 \pm 0.03$ & $0.64 \pm 0.03$ & $0.64 \pm 0.03$ & $0.61 \pm 0.04$ \\
\hline Liver $\quad(\mathrm{g} / 100 \mathrm{~g} B W)$ & $2.43 \pm 0.14$ & $2.25 \pm 0.05$ & $2.25 \pm 0.09$ & $2.36 \pm 0,07^{a}$ & $2.20 \pm 0.07^{a}$ & $2.08 \pm 0.10^{b}$ \\
\hline Spleen (mg/100 g BW) & $95 \pm 6$ & $102 \pm 11$ & $90 \perp 9$ & $99 \pm 9$ & 11317 & $89 \pm 15$ \\
\hline Bursa (mg/100g BW) & $362 \pm 63$ & $328 \pm 17$ & $315 \pm 16$ & $339 \pm 38$ & $358+11$ & $377 \pm 61$ \\
\hline Thymus (mg/100g BW) & $658 \pm 60$ & $650 \pm 51$ & $546 \pm 36$ & $696 \pm 70$ & $656 \pm 76$ & $553 \pm 25$ \\
\hline
\end{tabular}

Probability $>\mathrm{F}$

\begin{tabular}{ccccccc}
\hline & & \multicolumn{4}{c}{ Weight of } \\
\cline { 5 - 7 } d.f. & $\begin{array}{c}\text { Body weight } \\
\text { gain }\end{array}$ & $\begin{array}{c}\text { Feed } \\
\text { effiency }\end{array}$ & liver & spleen & bursa & thymus \\
\hline 1 & NS & NS & NS & NS & NS & NS \\
2 & NS & NS & $*$ & NS & NS & $*$ \\
2 & NS & NS & NS & NS & NS & NS
\end{tabular}

Significance of effects

AA

Density

A A $\times$ Density

1. MeantSE with 12 observations.

2. Mean $\pm S E$ with 6 observations in $217 \mathrm{~cm}^{2}$ per chick and 3 observationins 325 and $625 \mathrm{~cm}^{2}$ per chick, respectively.

3. Mean $\pm \mathrm{SE}$ with 6 observations.

$a, b$; Significant difference within the same AA level $(P<0.05)$.

Initial body weight was $160 \pm 5 \mathrm{~g} .{ }^{*}, \mathrm{P}<0.05 .^{* *}, \mathrm{P}<0.01$. NS, not significant. 
bursa and spleen did not significantly differ between treatments. Bursa weight, however, tended to be decreased with the higher stocking density in chicks fed the basal diet. Thymus weight significantly decreased with the increasing stocking density regardless of supplement with AA.

Table 3 shows effect of supplemental AA and/or stocking density on plasma concentrations of lipids, cholesterol and corticosterone, and carcass fat content in chicks. Plasma lipid concentration was significantly decreased by the supplemented AA. The increased stocking density and supplemental AA significantly reduced the plasma cholesterol concentration. The reducing effect of the supplemented AA on the plasma cholesterol concentration appeared to be effective in chicks kept at the higher stocking density. The stocking density and AA significantly affected plasma corticosterone concentration. The highest values of the plasma corticosterone concentration were observed in chicks kept at the density of $217 \mathrm{~cm}^{2}$ per chick and the lowest were observed in chicks kept at the density of $325 \mathrm{~cm}^{2}$ per chick regardless of supplement with AA. The supplemented AA significantly reduced the plasma corticosterone concentration. A significant interaction between the stocking density and AA was found for the plasma corticosterone. Carcass fat content was in the range of about 12 to $13.5 \%$ and did not differ among the treatments.

Table 4 shows the effect of supplemental AA and/or stocking density on contents of cytochromes P-450 and b 5 , activities of NADPHcytochrome $c$ reductase and NADH-cytochrome b 5 reductase in hepatic microsomes of chicks. The content of cytochrome b5 significantly decreased with the increase in the stocking density. There was a tendency toward decreasing the content of cytochrome $\mathrm{P}-450$ associated with the increased stocking density. Supplemental AA significantly increased the contents of cytochromes $P-450$ and $b 5$. The activity of NADPH-cytochrome $c$ reductase was significantly decreased by the supplemental AA, but not affected by the changes in stocking density. Significantly decreased activity of NADHcytochrome b 5 reductase was observed in

Table 3. Effect of supplemental ascorbic acid (AA) and/or stocking density on plasma concentration of lipids, cholesterol, and corticosterone and carcass fat content in chicks

\begin{tabular}{|c|c|c|c|c|c|c|}
\hline \multirow{2}{*}{$\begin{array}{l}\text { AA }(\%) \\
\text { Density }\left(\mathrm{cm}^{2} / \mathrm{chick}\right)\end{array}$} & \multicolumn{3}{|c|}{0} & \multicolumn{3}{|c|}{0.2} \\
\hline & 625 & 325 & 217 & 625 & 325 & 217 \\
\hline \multicolumn{7}{|l|}{ Plasma } \\
\hline lipid $(\mathrm{mg} / 100 \mathrm{mg})$ & $464 \pm 15$ & $462 \pm 21$ & $446 \pm 19$ & $414 \pm 20$ & $394 \pm 14 \#$ & $391 \pm 23$ \\
\hline cholesterol $(\mathrm{mg} / 100 \mathrm{~m} l)$ & $136 \pm 6^{a}$ & $127 \pm 9^{a}$ & $106 \pm 7^{b}$ & $112 \pm 3^{\text {a } \# ~}$ & $121 \pm 4^{\mathrm{a}}$ & $108 \pm 5^{b}$ \\
\hline corticosterone $(\mathrm{ng} / \mathrm{m} l)$ & $9.2 \pm 1.4^{D}$ & $7.8 \pm 1.3^{\circ}$ & $42.3 \pm 11.5^{\mathrm{a}}$ & $4.4 \pm 0.8 \#$ & $3.1 \pm 0.6 \#$ & $5.2 \pm 1.0 \#$ \\
\hline \multirow[t]{3}{*}{ Carcass fat $(\mathscr{\%})$} & $12.1 \pm 0.9$ & $13.3 \pm 0.5$ & $12.2 \pm 0.4$ & $12.5 \pm 0.7$ & $12.1 \pm 0.6$ & $12.5 \pm 0.7$ \\
\hline & \multicolumn{6}{|c|}{ Probability $>\mathrm{F}$} \\
\hline & d.f. & Lipids & Choleste & & Corticosterone & Carcass fat \\
\hline \multicolumn{7}{|l|}{ Significance of effects } \\
\hline $\mathrm{AA}$ & 1 & $* *$ & $*$ & & $* *$ & NS \\
\hline Density & 2 & NS & ** & & ** & NS \\
\hline AA $\times$ Density & 2 & NS & * & & $* *$ & NS \\
\hline
\end{tabular}

1. Means $+\mathrm{SE}$ with 6 observations. *, $\mathrm{P}<0.05$. **, $\mathrm{P}<0.01$. NS, not significant.

$a, b ;$ Significant difference within the same AA level $(P<0.05)$.

\#; Significant difference within the same stocking density $(\mathrm{P}<0.05)$. 
Table 4. Effect of supplemental ascorbic acid (AA) and/or stocking density on content of cytochrome P-450 and cytochrome b5, and activity of NADPH-cytochrome c reductase and NADHcytochrome b5 reductase in hapatic microsomes per unit of $100 \mathrm{~g}$ body weight of chicks

\begin{tabular}{|c|c|c|c|c|c|c|}
\hline \multirow{2}{*}{$\begin{array}{l}\text { AA }(\%) \\
\text { Stocking density }\left(\mathrm{cm}^{2} / \text { chicks }\right)\end{array}$} & \multicolumn{3}{|c|}{0} & \multicolumn{3}{|c|}{0.2} \\
\hline & 625 & 325 & 217 & 625 & 325 & 217 \\
\hline Cytochrome P-4502 & $6.3 \pm 0.9$ & $5.9 \pm 0.6$ & $5.2 \pm 1.1$ & $7.7 \pm 0.9^{a}$ & $7.8 \pm 0.6^{\mathrm{a}}$ & $\# 5.6 \pm 0.4^{\mathrm{b}}$ \\
\hline Cytochrome b5 2 & $10.3 \pm 0.7^{a}$ & $8.7 \pm 0.6^{a b}$ & $7.4 \pm 1.1^{b}$ & $11.6 \pm 1.2 \#$ & $12.2 \pm 0.6 \# 1$ & $10.0+0.6$ \\
\hline NADPH-cytochrome c reductase ${ }^{3}$ & $831 \pm 74$ & $775 \pm 40$ & $707 \pm 68$ & $496 \pm 29 \#$ & $542 \pm 35 \#$ & $520 \pm 23 \#$ \\
\hline NADH-cytochrome b5 reductase 4 & $12.1 \pm 0.7^{a}$ & $10.7 \pm 0.7^{3}$ & $7.8 \pm 0.6^{b}$ & $9.6 \pm 0.6 \#$ & $9.2 \pm 0.5$ & $8.9 \pm 0.5$ \\
\hline
\end{tabular}

Probability $>\mathrm{F}$

d.f. Cytochrome P-450 Cytochrome b5 NADPH-cytochrome c NADH-cytochrome b5

Significance of effects

AA $\quad$ *

Density 2 NS

AA $\times$ Density 2

NS

$\begin{array}{cc}* * & * * \\ * & \text { NS } \\ \text { NS } & \text { NS }\end{array}$

1. Mean $\pm \mathrm{SE}$ with 6 observations.

2. nmol/100 $\mathrm{g}$ body weight.

3. $\mathrm{nmol} / \mathrm{min} / 100 \mathrm{~g}$ body weight.

4. $4 \mathrm{~mol} / \mathrm{min} / 100 \mathrm{~g}$ body weight.

$a, b$; Significant difference within the same AA level $(P<0.05)$.

\#; Significant difference within the same stocking density $(P<0.05)$.

$*, P<0.05$. **, $\mathrm{P}<0.01$. NS, not significant.

Table 5. Correlation coefficients among the components of MFO and Plasma lipids, cholesterol and corticosterone and carcass fat

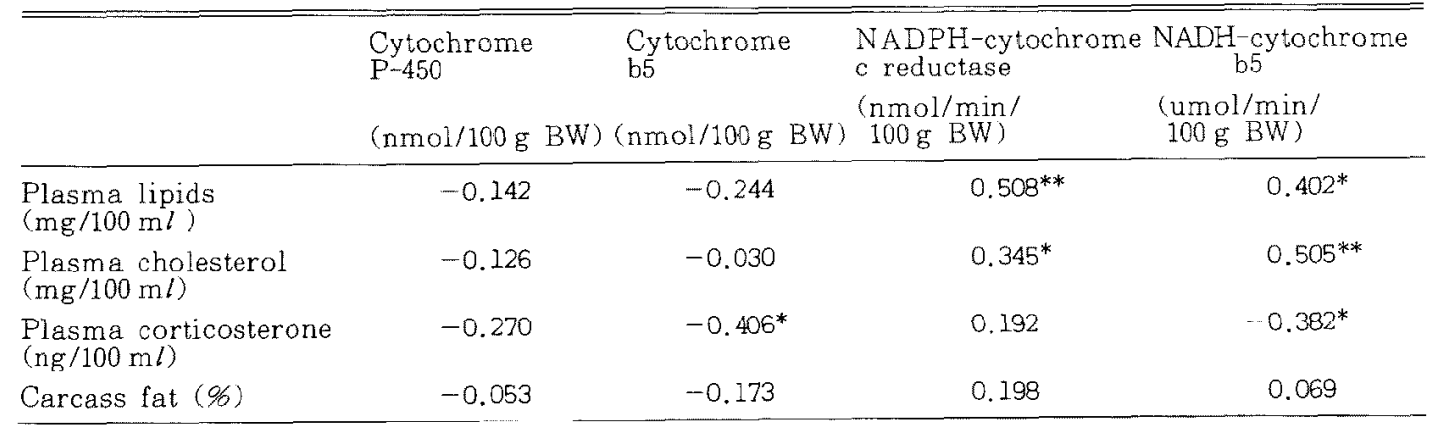

* $, \mathrm{P}<0.05 .{ }^{* *}, \mathrm{P}<0.01$.

chicks kept at the higher stocking density. The supplemental AA tended to decrease the activity of $\mathrm{NADH}-\mathrm{cyt}$ tochrome b 5 reductase. There was a significant interaction between the stocking density and supplemental AA for NADH-cytochrome b 5 reductase.

Table 5 shows correlation coefficients between the components of MFO per $100 \mathrm{~g}$ body weight and plasma concentrations of lipids, cholesterol and corticosterone and carcass fat content. Plasma lipids and cholesterol concentrations were, significantly, positively correlated with hepatic microsomal NADPH-cytochrome $c$ reductase and $\mathrm{NADH}$-cytochrome $\mathrm{b} 5$ reductase per $100 \mathrm{~g}$ of body weight. The plasma corticosterone concentration was, significantly, negatively correlated with hepatic microsomal cytochrome b5 content and the activity of 
$\mathrm{NADH}$-cytochrome b 5 reductase per $100 \mathrm{~g}$ body weight. No significant correlation was found between the components of MFO and carcass fat content.

\section{Discussion}

In the present experiment, the stocking density of 217,325 or $625 \mathrm{~cm}^{2}$ per chick did not significantly affect body weight gain and feed efficiency from 1 to 3 weeks of age: this is consistent with the result of PESTI and How ARTH ${ }^{34)}$ although the deleterious effects of the high stocking density on the growth of chicks has been reported by some investigators $^{7,20)}$. PESTI and Ilowarth ${ }^{34)}$ and DAFWANG et $a l{ }^{12)}$ observed that the stocking density of about $100-140 \mathrm{~cm}^{2}$ per chick decreased body weight gain and feed efficiency as compared to that of over $200 \mathrm{~cm}^{2}$ per chick. These results indicate that less than $150 \mathrm{~cm}^{2}$ per chick of stocking density, at least, should be required in order to induce growth depression by changes in stocking density at this age. It seems that chicks might reduce body weight gain if they are kept at the $217 \mathrm{~cm}^{2}$ per chick for long periods because higher corticosterone concentration was observed at this density. Our experiment also reconfirmed the results of the experiments that dietary AA did not stimulate consistently the growth of chicks fed nutritionally adequate diets and maintained under "nonstressed" conditions ${ }^{9,26 \text { ). }}$

The thymus weight significantly decreased in chicks subjected to $217 \mathrm{~cm}^{2}$ per chick, and corticosterone concentration in the plasma was higher at this stocking density. The results possibly support the hypothesis that the stocking density affected immunocompetence, since it has been known that the plasma corticosterone was increased under certain stressful condition, and that administration of corticosterone reduced immunity and immunocompetent organ weight ${ }^{16,18,301}$. On the other hand, DAFWANG et al. ${ }^{12)}$ suggested that the stocking density did not appear to affect antibody titur to sheep red blood cell (SRBC) and spleen weight. Thus, the effect of the stocking density on the immunocompetence of chicken has remained obscure. The supplemental AA served as an anti-immunosuppressive agent in chicks administrated with cortisol at pharmacological level ${ }^{30)}$. MCCORkLE et al. ${ }^{24)}$ showed that the AA supplementation in chicks kept at "nonstressed" condition did not affect antibody production to a T-lymphocyte dependent antigen such as SRBC. It is recognized that the thymus is a maturation center in which stem cells differentiate into T-lymphocytes ${ }^{32}$. Combined with the results of MCCORKLE and the present study that supplemental AA did not affect weights of immunocomptent organs, the supplemental AA would not affect, at least, T-lymphocyte dependent immunity under "nonstressed" conditions.

The present experiment first demonstrated that the stocking density and supplemental AA affected the components of the MFO. However, it is not surprising that the stocking density affected MFO activity since it has been established that many hormones including glucocoriticoids modified, directly or indirect$l y$, the MFO activity in hepatic microsomes of mammals which were unable to synthesize $\mathrm{AA}^{23)}$. It is known that dietary $\mathrm{AA}$ affects MFO activity in mammals. AA deficiency in guinea pigs, which essentially require AA for the normal growth and the normal metabolism of nutrients, reduced the MFO activity in hepatic microsomes ${ }^{46)}$. It has also been shown that ingestion of xenobiotics would increase the requirement of ascorbic acid several-fold for inducing the maximum activity of drugmetabolizing enzymes in mammals ${ }^{22)}$. The mode of action of AA to increase hepatic microsomal MFO of mammals has been considered as follows : a) inhibition of cytochrome degradation and/or promotion of cytochrome synthesis, b) maintenance of phospholipid structure in endplasmaic reticulum, and c) protection of occurrence of lipid peroxida- 
tion ${ }^{46)}$. On the other hand, the cause of changes in the MFO activity of chicks fed a diet containing $\mathrm{AA}$ is not clearly explainable since chicks used in the present study were not treated with any particular xenobiotics and are capable of synthesizing AA. Another question is why components of the MFO changed in opposite directions to each other due to $\mathrm{AA}$ feeding.

A higher corticosterone may be a factor for increasing the fat deposition in broiler chicks $^{2,4,5}$. The results of our experiment showed that the body fat content did not change even when the plasma corticosterone concentration was changed by the stocking density and/or supplemental AA. The different results between the earlier works and the present experiment may be caused by the experimental periods. When dietary and environmental conditions change, hormones will respond firstly, and, thereafter, nutrient utilization or retention may change. The concept was approved by the results of the time course studies with chicks ${ }^{3.43)}$ of the changes in dietary composition, the plasma estrogen concentration and liver lipid deposition. The plasma corticosterone concentration was significantly reduced by feeding a diet with $0.2 \% \mathrm{AA}$ in this experiment with broiler chicks, being in good accordance with the results of the experiment with laying hens treated with or without 150 ppm $\mathrm{AA}^{28)}$. According to SCHMELING and NockELS ${ }^{3 B\rangle}$, the corticosterone synthesis would be inhibited by feeding $A A$ in mature hens : In the hens fed $A A$, the pool size of the plasma corticosterone was smaller and its excretion rate was slower than the hens which received no AA. The MFO in hepatic microsomes is known to play an important role in steroid metabolism and an activation of the $\mathrm{MFO}$ in hepatic microsomes would be related to an increasing production of water soluble products from steroids ${ }^{41}$. The present experiment showed that supplemental AA significantly changed the activity of the MFO in hepatic micro- somes, and a significant negative correlation was observed between the plasma corticosterone concentration, and the content of cytochrome $\mathrm{b} 5$ and the activity of NADPHcytochrome b 5 reductase. A possible explanation for the reduction of the plasma corticosterone concentration by supplemental $\mathrm{AA}$ would be that an increase in the MFO activity in hepatic microsomes accelerated the rate of hydroxylation of a corticosterone. Although this would be supported by the in vitro results that drug-activated MFO produced more hydroxylated metabolites of corticosterone than an inactivated $\mathrm{MFO}^{103}$, further study is required to define our concept.

The reducing effect of supplemental AA on blood cholesterol has been demonstrated in rats and rabbits given a high cholesterol diet ${ }^{38}$ and chicks treated with propylthiouracil ${ }^{40 !}$. This study reconfirmed the effect of supplemental AA on the plasma cholesterol concentration in broiler chicks even when they were fed a nutritionally adequate diet. On the other hand supplemental AA did not affect the plasma cholesterol concentration in hens ${ }^{27}$. Different responses between the results of laying hens and broiler chicks are not explained at this time. In studies of liver homogenate and in situ liver perfusions, cholesterol synthesis from mevalonate was significantly depressed in the AA-deficient guinea pigs when compared to the control ${ }^{45}$. MFO in the liver plays an important role in the 7- $\alpha$-hydroxylation of cholesterol during the conversion of bile acids to cholesterol. The AA-deficient guinea pigs reduced the activity of this rate-limiting step in cholesterol metabolism ${ }^{5}$, leading to an accumulation of cholesterol in tissues and blood. As described above, chickens are able to synthesize AA but guinea pigs are not. However, metabolic demand of AA in chickens probably increases when they receive particular stress ${ }^{30,31,33)}$. The present experiment has shown that the AA requirement for maintaining normal lipid and steroid metabolism and, the 


\section{Takahashi, Nishimura, Akiba and Horiguchi}

MFO function may exceed, at least in part, amounts of AA biosynthesis in chicken under the condition of the present experiment. However, we have not demonstrated whether the responses of cholesterol metabolism and MFO activity foward AA in chicks are similar as are those observed in guinea pigs.

\section{References}

1) AкiBa, Y. and T. Matsumoto, Effects of force-feeding and dietary cellulose on liver lipid accumulation and lipid deposition of liver and plasma in growing chicks. J. Nutr., 108: 739-748. 1978

2) Akiba, Y., H. Miura and M. Horiguchi, Lipid accumulation and lipid metabolism in liver and adipose tissue and plasma corticosterone concentration of broiler chicks fed different protein sources or NKK-100. Jpn. Poultry Sci., 24 : 220-229. 1987.

3) Akiba, Y. and L.S. Jensen, Temporal effect of changes in diet composition on plasma estradiol and thyroxine concentrations and hepatic lipogenesis in laying hens. J. Nutr., 113 : 2178-2184. 1983

4) Bartov, I., Effect of dietary protein concentration and corticosterone injections on energy and nitrogen balance and fat deposition in broiler chicks. Br. Poult. Sci., 26 : 311-324. 1985.

5) Bartov, I., L.S. JeNSEN and J.R. VeLtMan, Effect of dietary protein and fat levels on fattening of corticosterone-injected broiler chicks. Poultry Sci., 59: 1864-1872. 1980.

6) Buörkнem, I. and A. Kallner, Hepatic $7-\alpha$-hydroxylation of cholesterol in ascorbate-deficient and ascorbate supplemented guinea pigs. J. Lipid Res. 17:360-365. 1976.

7) Bolton, W., W.A. Dewar, R. Morley, R, JONES and R. THOMPSON, Effect of stocking density on performance of broiler chicks. Br. Poult. Sci., 13 : 157-162. 1972.

8) BRAGDon, J.H., Method for determination of total serum lipids. in Lipid and the Steroid Hormones in Clinical Medicine (Sunderman, F.W. ed) 9-15. Lippinoct Philadelphia. 1960.

9) Briggs, G.M. Jr., T.D. Luckey, C.A. ELVEHJEM and E.B. HART, Effect of ascor- bic acid on chick growth added to purified rations. Proc. Soc. Exp. Biol. Med., 55 : 130-134. 1944.

10) Conney, A.H., K. Schneidman, M. JacobSON and R. KantzmZn, Drug-induced changes in steroid metabolism. Ann NY Acad. Sci., 12 : 98-109. 1965.

11) Craig, J.V. and A.W. Adams, Behavior and well-being of hens (Gallus Domestics) in alternative housing environment. World's Poultry Sci. J., 40: 221-240. 1984.

12) Dafwang, I.I., M.E. CoOK and M.L. SUNDE, Interaction of dietary antibiotics supplementation and crowding density on broiler chick performance and immune response. Br. Poult. Sci., 28: 47-55. 1987.

13) Folch, J., M. Lees and G.H. SloaneStANLEY, A simple method for the isolation and purification of total lipids from animal tissues. J. Biol. Chem., 226: 497509. 1957.

14) Fowler, K.C., G.M. Pesti and B. HowarTh, The determination of plasma corticosterone by high pressure liquid chromatography. Poultry Sci., 62: 10751079. 1983.

15) Freeman, B.W., Stress and the domestic fowl, A physiological re-appraise. World's Poultry Sci. J. 32 : 249-256. 1976.

16) Glick, B., Antibody and gland studies in cortisone and ACTH-injected birds. J. Immunol, 98: 1076-1084. 1967.

17) Golub, M.S. and M.E. Gershwin, Stressimmunodulation: What is it, if it is ? in Animal Stress. (Moberg, G.P. ed.) 177192. American Physiological Society. Bethesda. Maryland. 1985.

18) Gross, W.B. and P.B. Siggel, Effect of social stress and steroids on antibody production. Avian Disease, 17: 807-815. 1973.

19) Gross, W.B., P.B. Sirgez and R.T. Dubose, Some effects of feeding corticosterone to chickens. Poultry Sci., 59:516522. 1980

20) Hansen, R.S. and W.A. Becker, Feeding space, population density and growth of young chickens. Poultry Sci., 39: 654-661. 1960.

21) HrLl, J.A., Indications of stress in poultry. World's Poultry Sci. J., 39:2432. 1983.

22) Kato, N., K. KawaI and A. Yoshida, 
Effect of dietary level of ascorbic acid on growth, hepatic lipid peroxidation and serum lipids in guinea pigs fed polychlorinated byphenyls. J. Nutr, , 111 : 17271733. 1981.

23) Kato, R., in Yakubututaisha, (Kato, R. ed.) 98-124. Koudansya. Tokyo. 1974. (in Japanese).

24) Mc Corkle, F., R. TAylor, R. Stinson, E.J. MAY and B. GLICK, The effect of a megalevel of vitamin $c$ on the immunoresponse of chicks. Poultry Sci., 59: 13241327. 1980.

25) Moberg, G.P., Biological response to stress : Key to assessment of animal well-being? in Animal Stress. (Moberg G.P. ed.) 27-49. American Physiological Society. Bethesda. Maryland. 1985.

26) Nakaya, T., S. Suzuki and K. Watanabe, Effect of high dose supplementation of ascorbic acid on chicks. Jpn. Poultry Sci., $23: 276-283.1986$. (in Japanese),

27) Nockels, C.F., Effects of chick age and ingestion of ascorbic acid by the dam on plasma cholesterol. Poultry Sci., 51 : 2108 2110. 1972.

28) Nockels, C.F., G.A. Lopetz and R.W. Phillips, Influence of vitamin $A$ and $C$ on corticosterone and carbohydrate metabolism in chicks. Poultry Sci., 52 : 1261-1269. 1973.

29) OMURA, T. and R. SATo, The carbon monoxide-binding pigment of liver microsomes. J. Biol. Chem., 239: 2370-2378. 1964.

30) Pardue, S.L. and J.P. Thaxton, Evidence for amelioration of steroid-mediated immunosuppression by ascorbic acid. Poultry Sci., 63 : 1334-1338. 1984.

31) Pardue, S.L., J.P. Thaxton and J. Brake, Influence of supplemental ascorbic acid on broiler performance following exposure to high environmental temperature. Poultry Sci., 64 : 1334-1338. 1985.

32) PAyne, L.N. and P.C. Powell, The Lymphoid system. in Physiology and Biochemistry of the Domestic Fowl. vol 5 . (FreEman, B.M. ed.) p 278-308. Academic Press. London. 1984.

33) Peeble, E.D. and J. Brake, Relationship of dietary ascorbic acid to broiler breeder performance. Poultry Sci., 64 : 2041-2048. 1985.
34) Pesti, G.M. and B. Howarth, Effects of population density on the growth, organ weights, and plasma corticosterone of young broiler chicks. Poultry Sci., 62: 1080-1083. 1983.

35) Phillips, A.H. and R.G. Landon, Hepatic triphosphopyridine nucleotide cytochrome c reductase: isolation, characterization and kinetics studies. J. Biol. Chem., 237 : 2652-2650. 1962.

36) Schmeling, S.K. and C.F. Nockels, Effect of age, sex, and ascorbic acid ingestion on chicken plasma corticosterone levels. Poultry Sci., 57: 527-533. 1978.

37) Scott, N.R. and P.F. Dixon, Determination of cortisol in human plasma by reversed-phase high-performance liquid chromatography. J. Chromot., $164: 29-34$. 1979.

38) SoKoloff, B., M. Hori, C. Saelhof, B. MCCunell and T. IMAI, Effect of ascorbic acid on certain blood fat metabolism factors in animals and man. J. Nutr., 91 : 107-118. 1967.

39) Statistical Analysis System 1983. User's guide 1983 edition. Raleigh, North Calorinia.

40) Takahashi, K, Y. Akiba and M. HoriGUCHI, Effects of supplemental ascorbic acid on performance, organ weight and plasma cholesterol concentration in broilers treated with propylthiouracil. Br. Poultry Sci., 1991. in press.

41) Takahashi, K. and L.S. Jensen, Effect of dietary composition and estradiol implants on hepatic microsomal mixed function oxidase and lipid deposition in growing chicks. Poultry Sci., 63:22172224. 1984.

42) Takahashi, K. and L.S. Jensen, Reduction in hepatic lipid and plasma estradiol in estrogenized chicks injected with ascorbic acid. Proc. Soc. Exp. Biol. Med., 178 : 200203. 1985.

43) Takahashi, K. and L.S. Jensen, Time course study of liver lipid, mixed function oxidase, and estradiol metabolism in laying hens fed different diet. Poultry Sci., 66: 1660-1664. 1987.

44) Takesue, S. and T. Omura, Purification and properties of NADH-cytochrome $\mathrm{b} 5$ reductase solublized by lysosomes from rat liver microsomes. J. Biol. Chem., 267 : 
Takahashi, Nishimura, Akiba and Horiguchi

2278-2283. 1970

45) Weight, M.J., K. COMPton-James, D.J. Van Schalkwyki and J.V. Seier, Cholesterol-ascorbic acid interactions in guinea pig liver homogenates, and the in situ perfused liver: Relationship between ascorbic acid status and cholesterol and bile acid synthesis form mevalonate. Int. J.
Vit. Nutr. Res. 52 : 298-306. 1982.

46) Zannoni, V.G. and P.H. Sato, The effect of certain vitamin deficiencies on hepatic drug metabolism. Fed. Proc., 35 : 24642469. 1976.

47) ZuRkowski, P., A rapid method for cholesterol determination with single agent. Clin. Chem., 104: 451-453. 1964.

\title{
雄ブロイラーの成長, 藏器重量, 脂質代謝, 肝臓 \\ ミクロソーム薬物代謝䤉素活性抒よび血漿 \\ コルチコステロン濃度に対する飼育密度と \\ アスコルビン酸涯加の影響
}

\author{
高橋和昭・西村 仁・秋葉征夫・堀口雅昭 \\ 東北大学農学部，仙台市青葉区 981
}

\begin{abstract}
雄ブロイラーの成長, 缄器重量, 脂質代謝, 肝臟ミクロソーム薬物代謝醏素活性抢よび血漿コルチコ ステロン澧度に対する飼育密度とアスコルビン酸添加の影響を検討した．7日路の雄ブロイラーを 217 ， $325,625 \mathrm{~cm}^{2} /$ 鶏の飼育密度で 14 日闒飼育し，それぞれの飼育密度の半数の鶏には $0.2 \%$ アスコルビ

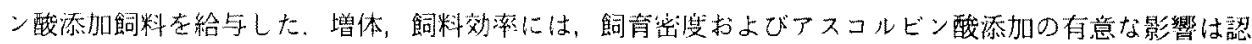
められなかったが，アスコルビン酸無添加区では，飼育密度の增加に上もない增体が低下する傾向がみ られた，胸腺重量は，アスコルビン酸添加の有無にかかわらず高鸰育密度条件下で低下した，血漿中コ レステロールおよび脂質濃度は，飼育密度の増加およびアスコルビン酸添加により低下した，血墏コル チコステロン溜倿む、アスコルビン酸添加により低下した，体脂肪含量は，飼育密度およびアスコルビ

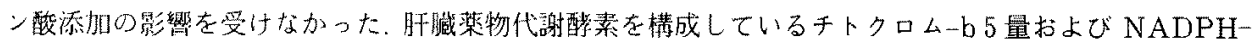

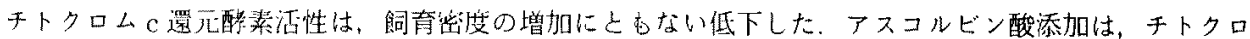

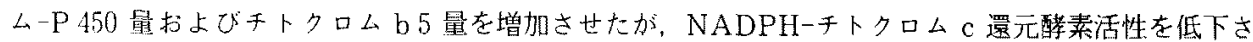

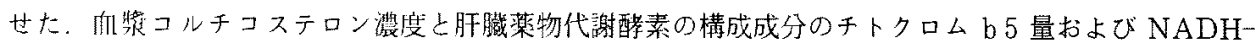
チトクロムb 5 還元酳菜活性の間には負の町関が認められた。これらの結果は，成長に影響を及ぼさ ない条件下の飼育密度扰よびアスコルビン酸添加が，雄ブロイラーの脂質代謝，肝葴薬物代謝醉菜活性

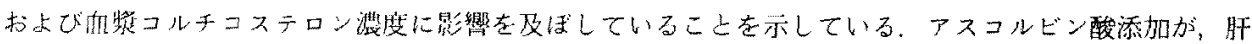

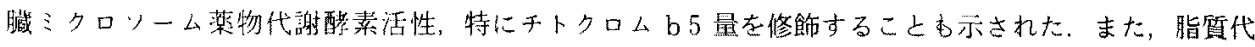

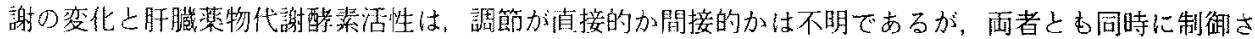
れていることが示唆された。
\end{abstract}

